УДК 343.9.01

DOI https://doi.org/10.32837/pyuv.v1i4(29).414

\author{
С. В. Щоголєв \\ orcid.org/0000-0002-1873-848X \\ аспірант відділу аспірантури і докторантури \\ Національної академії Служби безпеки України
}

\title{
ЕВОЛЮЦІЯ ОРГАНІЗОВАНОЇ ЗЛОЧИННОСТІ В УКРАЇНІ (ОКРЕМІ АСПЕКТИ)
}

Вступ. Сучасна організована злочинність становить глобальну загрозу, що так чи інакше стосується усіх країн світу, незважаючи на рівень розвитку, політичний та економічний лад. Попри процеси глобалізації, конкретні прояви злочинності в різних державах та регіонах мають свою специфіку, що визначається історичними передумовами, національними особливостями розвитку суспільства, економіки та політичної сфери. Спільні риси організованої злочинності держав пострадянського простору визначаються історичними чинниками, спільним перебуванням в складі Союзу Радянських Соціалістичних Республік (далі - СРСР). Вивчення цих рис з огляду на їх унікальність саме для організованої злочинності на теренах пострадянських країн ми вважаємо $a \kappa$ туальним.

Мета статті - розглянути окремі аспекти еволюції організованої злочинності в Україні в контексті інкорпорації організованих злочинних угруповань, що сформувалися на території України в радянські часи, до світової транснаціональної злочинної спільноти. Відповідно до мети визначено завдання дослідити та за можливості виокремити основні еволюційні стадії цього процесу.

Виклад основного матеріалу. У 1970-1980 pp. минулого століття посилилися тенденції протистояння між державою та суспільством, інтереси яких часто були протилежними. Окремі верстви суспільства подекуди самоідентифікували себе більше із криміналітетом, аніж зі владою. Протиправна діяльність часто розглядалася як спосіб отримати те, на що людина має природне право, але не може набути законним шляхом. Це призвело до поширення правового нігілізму серед широких верств населення, формування не лише історичних передумов, а й соціальної бази організованої злочинності. У часи СРСР зазначені вище тенденції мали значний вплив на розвиток ситуації на цьому географічному просторі, оскільки модель управління державою, попри суттєві зміни, залишалася авторитарною [1].

Обмежена здатність держави задовольняти потреби населення у товарах повсякденного вжитку створила передумови для формування тіньової економіки, орієнтації організованої злочинності на легальний сектор економіки. Отже, поступово почали створюватися умови для формування єди- ного конгломерату «криміналітет - економіка політика», що і досі виступає домінуючою формою організованої злочинності на пострадянському просторі. Тіньова економіка тісно інтегрувалася у легальну, при цьому відносини між легальними суб'єктами підприємництва часто здійснювалися iз використанням тіньових механізмів. Корупційні відносини стали чи не єдиним механізмом забезпечення функціонування навіть суто легального сектору економіки.

У більшості регіонів СРСР (в тому числі і в тодішній Українській Радянській Соціалістичні Республіці) стійкі кримінальні відносини, учасниками яких були представники політичної еліти, сформувалися вже у 1970 -ті роки і у певному сенсі сформували модель, за якою ситуація розвивалася із кінця 1980 -х років. Період «перебудови» (сер. 1980-х - поч. 1990-х років) ознаменувався фактичною легалізацією тіньового сектору. Приватний бізнес, сформований в умовах протистояння державній владі, легалізувався і визначив правила, за якими економіка розвивалася у подальшому. У цю сферу інтегрувалися політичні та господарські еліти СРСР, що капіталізували своє становище.

Водночас із цим відбувалася деідеологізація суспільного життя, яка полягала у відмові від застарілих радянських ідеологічних штампів, при цьому нові ідеологічні орієнтири суспільству не пропонувалися. Ідеї правової держави та верховенства права залишалися так само чужими для широкого загалу населення. Втрата ідеологічних орієнтирів призвела до подальшого поглиблення правового нігілізму населення, сприйняття можливості порушувати закон не лише для задоволення законних потреб, а й для досягнення життєвого успіху, особистого збагачення, зміни соціального статусу.

Саме цей період ознаменувався розквітом організованої злочинності у її різних формах. Це, зокрема, рекет, наркобізнес, викрадення автомобілів, торгівля зброєю, викрадення людей для отримання викупу, незаконні фінансові операції, економічна контрабанда тощо. Кримінальні структури встановлювали широкий територіальний контроль, фактично виводячи цілі регіони 3-під державного суверенітету. 3 іншого боку, такіструктуридоситьуспішновстановлювали 
контроль над цілими галузями економіки, а також інститутами державної влади. Інтеграція криміналітету та правоохоронних органів призвела до підміни злочинністю державних інститутів безпеки [1].

Поширення рекету наприкінці 1980-х - на початку 1990-х років дозволило проникнути до економічного сектору держави структурам організованої злочинності насильницького типу. Можна виділити низку характерних особливостей організованої злочинності пострадянського простору періоду кінця 1980-х - початку 1990-х років. Зокрема, це наявність спільної фінансової бази для спільних потреб (т.з. общаків). Такі фонди були характерними для організованої злочинності радянського періоду, але згодом вони почали використовуватися не лише для фінансової підтримки членів кримінальних структур, а й як джерело коштів, які використовувалися для започаткування бізнесу, з корупційною метою тощо.

Для структур організованої злочинності того періоду характерною була чітка ієрархічна побудова - від простих ієрархій типу «ватажок - виконавці" до складних структур мафіозного типу. Досить часто такі структури вбудовувалися у легальні інститути - органи влади, промисловофінансові групи тощо, встановлювали територіальний контроль. Досить типовою була ситуація, за якої такі структури перебували між собою у стані протистояння, у т.ч. пов'язаного із використанням насильницьких методів. Насильство також широко використовувалося у відносинах із зовнішнім середовищем - суспільством, правоохоронними органами (поруч із корупцією). У подальшому (кінець 1990-х - 2000-ні роки та подальший період) такі структури почали витіснятися плинними та гнучкими кримінальними мережами [2 с. 43].

Для ієрархічних структур типовими були чітка кримінальна спеціалізація, визначене членство, інколи пов' язане із певними ритуалами прийняття до лав, тісні та виражено персоналізовані зв'язки між учасниками, дисципліна, що досягалася шляхом застосування примусу та покарання порушників і відступників. Основою такої дисципліни були встановлені в організації правила та норми, відомі усім її членам, що регламентували досить широке коло відносин. Члени таких структур могли розраховувати на їх підтримку у разі особистих проблем, у т.ч. під час перебування у місцях позбавлення волі.

Процеси приватизації відбувалися майже виключно за кримінальною моделлю та з використанням корупційних схем і механізмів. Завдяки цьому об'єкти підприємництва, що створювалися впродовж десятиліть, перейшли у власність корупціонерів - колишніх директорів, посадових осіб - або до рук організованої злочинності.
Діяльність т.з. спільних підприємств на тому етапі фактично виступила формою транснаціоналізації організованої злочинності. Такі структури використовувалися для вчинення контрабандних акцій, легалізації доходів, одержаних злочинним шляхом, виведення капіталів за кордон.

У другій половині 1990-х років органи державної влади, зокрема правоохоронні, значною мірою витіснили 3 кримінального середовища традиційний рекет (принаймні ту його частину, що не встигла до того часу легалізуватися), зайнявши його місце. Основними сферами діяльності організованої злочинності у 1990-ті роки були наркобізнес, банківське шахрайство, торгівля зброєю, нелегальний експорт нафти та кольорових металів, контрабанда ядерних матеріалів та відходів [2, с. 67].

Відсутність на пострадянському просторі взагалі і в Україні зокрема режиму верховенства права, у т.ч. забезпечення права власності, сприяючи поширенню організованої злочинності, виступила обмежуючим чинником для можливості інвестування капіталів як легального, так і нелегального походження. Отже, однією із найважливіших рис організованої злочинності пострадянського простору стала орієнтація не лише на виражено кримінальну діяльність (наркобізнес, торгівлю людьми, зброєю тощо), а й на отримання прибутку від легального бізнесу шляхом встановлення незаконного контролю над ним і виведення його у тіньовий сектор.

Особливістю організованої злочинності на пострадянському просторі став їі виразний перерозподільний характер (від крадіжок та пограбувань до різного роду бюджетних розкрадань). При цьому сама злочинність формувалася не навколо певних економічних відносин, що притаманно для організованої злочинності в інших регіонах світу, а в місцях позбавлення волі, значною мірою під контролем держави. Традиційні злодії у законі були відокремлені від економічної діяльності, що сформувало виключно паразитарну систему, не здатну виробляти будь-які товари чи послуги, навіть заборонені законом. Зазначене стало визначальною рисою для організованої злочинності пострадянського простору. У більшості інших країн світу основою організованої злочинності $€$ злочинне підприємництво, тобто виробництво незаконних товарів та послуг і їх пропозиція на ринку. Основні кошти організована злочинність там отримує від таких дій, як наркобізнес, торгівля людьми, нелегальна міграція, тобто виробництво та пропозиція певних товарів, таких як наркотики, а також послуг, наприклад, у сфері секс-індустрії, незаконного використання робітничої сили, нелегального переправлення мігрантів. На пострадянському просторі ці види організованої злочинності не є основним джерелом злочинного прибутку. Найбільші кошти тут отримуються від 
незаконного перерозподілу бюджетних коштів, тобто вже наявних суспільних ресурсів. Навіть у зазначених вище сферах (наркобізнес, торгівля людьми тощо) найбільший прибуток отримується в результаті корупційних схем із прикриття такої діяльності. Організована злочинність тісно вбудовується у владну вертикаль, проникає в інститути держави, суспільства та економіки, що перетворюються на її легальні придатки.

Вплив такої злочинності на суспільство є вкрай небезпечним, у тому числі через свою латентність, здатність розкладати соціум із середини. Якщо протистояння організованої злочинності у формі злочинного підприємництва чи насильницького типу із суспільством є очевидним, то ситуація із злочинністю перерозподільного типу є менш явною. У систему корупції втягуються не лише окремі чиновники, а суспільство у цілому, що стає не лише жертвою, а й співучасником злочину. Перерозподільна злочинність деформує соціальні ліфти, створюючи певні умови для зміни соціального статусу за рахунок участі у незаконній діяльності, руйнуючи при цьому легальні усталені ліфти, такі як освіта, підвищення професійного рівня, участь в легальній економічній діяльності, новаторство тощо. Відбувається деформація суспільства у цілому, його перебудова за кримінальною моделлю.

Крім того, це призводить до спрощення самої злочинності. Підвищення кримінального професіоналізму, на відміну від злочинного підприємництва, перестає відігравати ключову роль. Більш важливими є причетність до певного клану (територіального чи родинного) та особисті якості, пов'язані зі здатністю брати участь у кримінальних оборудках та корупційних практиках.

Такого роду злочинність характеризується не просто тісним зв'язком із корупцією (остання $є$ ї̈ сутністю), адже здійснювати суттєвий перерозподіл суспільного капіталу на користь окремих осіб без застосування корупційних практик неможливо. Отже, загроза бути викритим та притягнутим до відповідальності для злочинців $є$ мінімальною. Ti самі механізми, що дозволяють вчиняти злочини, виводять злочинців з-під правового контролю. Це усуває потребу у конспірації та використанні витончених методів вчинення злочину. Злочинці пострадянського простору не тільки не приховують свого багатства, а й відкрито його демонструють.

3 середини 1990 -х років спостерігалася певна стабілізація ситуації, зумовлена як активізацією правоохоронної діяльності, зокрема щодо етнічної організованої злочинності та інших проявів кримінальної діяльності низового рівня, так і поділом сфер впливу між потужними кримінальними структурами, що до того часу зуміли легалізуватися.
Ознакою 2000-х років стала транснаціоналізація організованої злочинності на пострадянському просторі взагалі і в Україні зокрема. Така злочинність до цього часу мала лише епізодичний характер та проявлялася у встановленні зв'язків за кордоном та формуванням зарубіжних філій і представництв, що могли використовуватися із протиправною метою. Україна була місцем переховування та комфортного проживання членів організованої злочинності [3, с. 57-58]. Відбулося проникнення іноземних організованих злочинних угруповань як фактору транснаціоналізації у таких сферах злочинної діяльності, як наркобізнес, торгівля людьми, нелегальна міграція та торгівля зброєю. При цьому торгівля зброєю, у тому числі успадкованою від колишнього СРСР, набула досить значних масштабів і часто форми не лише транснаціональної, а й міжнародної злочинності, за якої зброя незаконно продається політичним режимам, на які розповсюджуються міжнародні санкції [4. с. 44].

Висновки. Розпад соціалістичної економіки, дезінтеграція СРСР, інституційна неспроможність та криміналізація політикуму призвели до широкої криміналізації суспільного життя на початку 1990 -х років. Вуличні банди консолідувалися у потужні кримінальні об'єднання, що почали усвідомлювати свої не лише економічні, а й політичні інтереси. Їх представники зайняли місця в органах влади на місцевому та на центральному рівнях, а отримані злочинним шляхом капітали трансформувалися у легальний бізнес.

Якщо на початку 1990-х років головними доходами організованої злочинності були доходи від рекету, то згодом вона досить швидко переорієнтувалася на злочинність корупційного типу. Відсутність належної системи державного управління створила невичерпні можливості для розвитку організованої злочинності, що стала єдиною силою, здатною забезпечити стабільність існування бізнесу, виплату боргів, повернення банківських кредитів. Злочинність взяла на себе державні функції, у т.ч. судової та виконавчої влади, а з 2000 -х набула міжнародного (транснаціонального характеру).

\section{Jimepamypa}

1. Soviet organized crime URL: https://www. globalsecurity.org/military/world/para/sovietorganized-crime.htm.

2. Багрий-Шахматов Л.В. Уголовно-правовые и криминологические проблемы коррупции, теневой экономики и борьбы с ними. Одесса : Латстар, 2001. 530 с.

3. Теневая экономика : учебное пособие для вузов / Ю.В. Латов, С.Н. Ковалев ; под ред. д.п.н., д.ю.н., проф. В.Я. Кикотя ; д.э.н., проф. Г.М. Казиахмедова. Москва : Норма, 2006. 336 с.

4. The Globalization of Crime. A Transnational Organized Crime Threat Assessment. United Nations Office on Drugs and Crime. Vienna. 2010. 303 c. 


\section{Анотація}

Щоголєв С. В. Еволюція організованої злочинності в Україні (окремі аспекти). - Стаття.

У статті розглянуто окремі аспекти еволюції організованої злочинності в Україні з 1960-х до 2000 -х років. Відзначено поширення правового нігілізму серед широких верств населення як формуючу ознаку історичних передумов та соціальної бази організованої злочинності в часи СРСР. Акцентовано увагу на формуванні єдиного конгломерату «криміналітет - економіка - політика», що досі виступає домінуючою формою організованої злочинності на пострадянському просторі. Приватний бізнес, сформований в умовах протистояння державній владі, легалізувався і визначив правила, за якими розвивається економіка. У цю сферу інтегрувалися політичні та господарські еліти СРСР, що капіталізували своє становище. Найбільш поширеними явищами організованої злочинності в Україні в 1990-х рр. визначено рекет, наркобізнес, викрадення автомобілів, торгівлю зброєю, викрадення людей для отримання викупу, незаконні фінансові операції, економічну контрабанду тощо. Наголошено на широкому територіальному контролі та контролі над галузями економіки, які встановлювалися киміналітетом. Автор зазначає, що для структур організованої злочинності того періоду характерною була чітка ієрархічна побудова (від простих ієрархій типу "ватажок - виконавці» до складних структур мафіозного типу, які згодом інтегрувалися у легальні інститути - органи влади, промислово-фінансові групи тощо). Автор вказує на те, що у другій половині 1990-х років органи державної влади, зокрема правоохоронні, значною мірою витіснили з кримінального середовища традиційний рекет, зайнявши його місце. Основними сферами діяльності тоді були наркобізнес, банківське шахрайство, торгівля зброєю, нелегальний експорт нафти та кольорових металів, контрабанда ядерних матеріалів та відходів. Автор доходить висновку, що розпад соціалістичної економіки, дезінтеграція СРСР, інституційна неспроможність та криміналізація політикуму призвели до широкої криміналізації суспільного життя на початку 1990-х років. Вуличні банди консолідувалися у потужні кримінальні об'єднання, що почали усвідомлювати свої не лише економічні, а й політичні інтереси. Ïх представники зайняли місця в органах влади на місцевому та на центральному рівнях, а отримані злочинним шляхом капітали трансформувалися у легальний бізнес.

Ключові слова: транснаціональна організована злочинність, Європейський Союз, протидія, Європол, криміналітет.

\section{Summary}

Shchoholiev S. V. The evolution of organized crime in Ukraine (selected aspects). - Article.

The article discusses some aspects of the evolution of organized crime in Ukraine from the early 1960s to the $1970 \mathrm{~s}$ to the $2000 \mathrm{~s}$. The spread of legal nihilism among the general population was noted as a formative feature of the historical preconditions and social base of organized crime in the USSR. The attention is focused on the formation of a unified conglomerate "criminality - economy - politics", which is still the dominant form of organized crime in the post-Soviet space. In the future, private business, formed in the face of opposition to the state government, legalized and defined the rules by which the economy developed in the future. Political and economic elites of the USSR were integrated into this sphere, capitalizing on their position. The most common organized crime in Ukraine in 1990 was identified as racketeering, drug trafficking, car theft, arms trafficking, kidnapping for ransom, illegal financial transactions, economic smuggling, etc. Emphasis is placed on broad territorial control and control over sectors of the economy established by crime. The author notes that the structures of organized crime of that period were characterized by a clear hierarchical construction - from simple hierarchies of the type "leader - executor" to complex structures of mafia type, which were further integrated into legal institutions - authorities, industrial and financial groups, etc. The author points out that in the second half of the 1990s the state authorities, in particular, law enforcement, largely supplanted the traditional racket from the criminal environment by taking its place, the main areas of activity at that time were drug business, banking fraud, arms trafficking, illegal export oil and non-ferrous metals, smuggling of nuclear materials and waste. The author concludes that the collapse of the socialist economy, the disintegration of the USSR, institutional failure and the criminalization of the politicum led to widespread criminalization of public life in the early $1990 \mathrm{~s}$. The street gangs consolidated into powerful criminal associations that began to realize not only their economic but also their political interests. Their representatives took the place of local and central authorities, and the proceeds of crime were transformed into legal businesses.

Key words: organized crime, USSR, crime counteraction, criminality, criminal activity. 